\title{
Türkiye Ormancılık Sektöründe Odun Dışı Orman Ürünleri: İhracat Analizi
}

\author{
Rıfat KURT ${ }^{*}{ }^{1}$, Selman KARAYILMAZLAR ${ }^{1}$, Erol IMREN ${ }^{1}$, Yıldız ÇABUK ${ }^{1}$ \\ ${ }^{1}$ Bartın Üniversitesi, Bartın Orman Fakültesi, 74100/BARTIN \\ rkurt@bartin.edu.tr
}

\section{ÖZET}

Türkiye ormanlarındaki zengin biyolojik çeşitlilik, ülkenin değişik yörelerinde yayllış gösteren ormanlar içinde zengin ODOÜ (Odun Dışı Orman Ürünleri) kaynaklarının yer almasına imkan sağlamaktadır. Bu kaynaklardan sağlanan ODOÜ'lerden gerek yerel, gerekse ülke bazında çok çeşitli ihtiyaçların karşılanmasında yararlanılmakta ve ihraç yoluyla da önemli sayılabilecek gelirler elde edilmektedir. Bu çalışmada Türkiye'nin dış ticaretinde önemli bir yere sahip olan defne, kekik, çam fistığı, adaçayı, kimyon, anason, ıhlamur ve kestane bitkilerinin 1995-2015 yılları arasındaki 21 yıllık ihracat durumu incelenmiş ve elde edilen bu veriler tasnif edildikten sonra grafik halinde sunularak yıllar itibariyle meydana gelen değişmeler yüzdesel hesaplamalarla ortaya konulmuştur.

Anahtar kelimeler: ODOÜ, Dış Ticaret, İhracat Gelir, İhracat Miktar

\section{NON-WOOD FOREST PRODUCTS IN TURKEY FORESTRY SECTOR: EXPORT ANALYSIS}

\begin{abstract}
Rich biological diversity of the forests in Turkey offers rich NWFP (Non-Wood Forest Products) sources in the forests in different parts of the country. These NWFP are utilized to meet a range of needs both locally and nationwide. And also significant income is generated through export. In this study, the export of bay leaves, thyme, pine nuts, sage, cumin, anise, linden and chestnut which have a significant places in Turkey export, for 21 years (between 1995 and 2015) were investigated. And the collected data were classified and presented in graphics. Thus, the changes by years are shown with percent calculations.
\end{abstract}

Keywords: NWFP, International Trade, Export Revenue, Export Amount

\section{GíRiş}

Günümüzde orman ürünü kavramı, ormanlardan elde edilen odun ve odun dışında kalan diğer yan ürünler olarak tanımlanmaktadır. Orman ana kaynağı olan odun hammaddesi dışında kalan her türlü bitkisel ve hayvansal ürünler ise odun dışı orman ürünleri (ODOÜ) olarak adlandırılmaktadır.

Dünya genelinde olduğu gibi Türkiye'de de odun dışı orman ürünlerinin en önemli kısmını Odun Dışı Bitkisel Orman Ürünleri oluşturmakta olup, Dünya Sağlık Örgütüne (WHO) göre, dünyada çeşitli amaçlarla kullanılan bitki sayısı 20.000 civarındadır. Bunlardan 4.000'i bitkisel ilaç olarak yaygın bir şekilde kullanılırken, yaklaşık $\% 10$ 'unun ticareti yapılmaktadır. Türkiye'de tıbbi olarak kullanılan bitkilerin sayısının 500 civarında olduğu tahmin edilmektedir. Ancak, doğadan toplanarak ticareti yapılan bitki türlerinin sayısının 346 olduğu ve bunların 112'sinin ihraç edildiği 24'ünün endemik olduğu ve endemik türlerin 7'sinin de halen ihraç edildiği belirtilmektedir. Örneğin adaçayı, kekik, çöven ve şalba'nın bazı türleri endemik olup ihraç edilen türlerdir. 
Bunun yanı sıra; doğadan toplanan ve aktarlar, semt pazarları ve marketler aracılığıyla ticareti yapılan türlerin sayısının da 179 olduğu tespit edilmiştir (Balcı, 2011).

Odun dışı orman ürünleri bazı ülkelerde veya ülkelerin bazı yörelerinde özellikle kırsal fakirliği azaltma ve yerel ekonomik gelişmeyi sağlama açısından önemli katkılar sağlamaktadır. Dünya nüfusunun \%80'inin özellikle sağlık ve gıda konusundaki ihtiyaçlarının ODOÜ'ler sayesinde karşılamaları, bu ürünlerin sosyo-ekonomik açıdan taşıdığı önemi göstermektedir (DPT 2001; Killmann vd. 2003). Bu noktada, sürdürülebilir faydalanma ve doğal dengenin korunması orman kaynakları yönetiminin ve bu kapsamda odun dışı orman ürünleri işletmeciliğinin temelini oluşturmaktadır (URL-1, 2016).

Orman Genel Müdürlüğünün son yıllarda başlatılan odun dışı orman ürünlerine yönelik yaptığı çalışmalar, her y1l artarak meyvesini vermeye devam ettirmektedir. Devlet İstatistik Kurumu verilerine göre 2000 yılında 30 milyon dolar olan odun dışı orman ürünü ihracatı, 2009 yılında 47 bin ton odun dışı orman ürünlerine karşılık 160 milyon dolara; 2010 yılında da 64 bin ton odun dışı orman ürünü karşılık 221 milyon dolara ulaştı̆ı belirtilmektedir. Böylece Orman Genel Müdürlüğü 2010 bilanço sonuçlarına göre üretilen 131 bin ton Odun dış1 orman ürünlerinin 67 bin tonu iç piyasada tüketilirken 64 bin tonu ihraç edilmiştir (URL-2, 2015). 2012 yılında ise bu değer 306 milyon dolara, 2013 yılında 436 milyon dolara ulaşarak giderek artış göstermektedir (URL-3, 2016).

Türkiye'nin 2010 yılı itibariyle odun dışı orman ürünleri sektöründe en fazla ihracat yaptı̆̆ ülke Çin'dir. Anılan sektörde Türkiye'nin toplam ihracatının \%15'i Çin'e yapılmaktadır Sektör ihracatında ikinci sırada yer alan ABD ise \%9,3 oranında pay almaktadır. Bu ülkeleri sırasıly Almanya $(\% 9,3)$, Vietnam $(\% 7,9)$ ve İspanya $(\% 6)$ takip etmiş̧ir (Sakarya ve Canl1, 2011).

\section{MATERYAL VE METOT}

Bu çalışmada ilk olarak odun dışı orman ürünleri içerisinde önemli bir paya sahip olan kestane, defne, kekik, çam fistığı, adaçayı, kimyon, anason ve ıhlamur gibi odun dışı orman ürünlerinin 1995-2015 yılları arasındaki ihracat verileri Türkiye istatistik kurumundan (TÜIK) elde edilerek tasnif edilmiş ve ürünlerle ilgili kalemler toplanarak grafik haline dönüştürülmüştür. Bu grafiklerden yola çıkılarak konu ile ilgili yorumlarda yüzdesel hesaplamalardan yararlanılmış ve Türkiye'nin 21 yıllık ihracat miktar ve parasal değerleri analiz edilmiştir.

Değerlendirmelerde ODOÜ'lerin hangi yıllarda daha fazla ihracat değerlerine sahip olduğu, hangi yıllarda düşüş gösterdiği, en fazla veya en az ihracat yapılan yıllar, en fazla ihraç edilen ülkeler incelenmiş ve bu ürünlerin parasal değerlerindeki değişimler irdelenmiştir.

Adı geçen orman ürünleri Türkiye'nin ODOÜ ihracatında öne çıan ürünlerden bazıları olup, ülkemizin ODOÜ ihracatının büyük bir bölümünü oluşturmaktadır. Bu nedenle bu odun dışı orman ürünlerinin ihracat miktarının arttırılması amacıyla son zamanlarda yürütülen çalışmaların etkili olup olmadığı ortaya konulmuş ve ODOÜ’ye verilen önemin daha da arttırılması amacıyla bazı önerilerde bulunulmuştur.

\section{BULGULAR}

Çalışmada belirtilen odun dışı orman ürünlerine ait genel bilgiler ve 21 yıllık ihracat değişmeleri ürün kalemleri halinde verilmiş̧ir.

\subsection{Kestane ihracatı}

Bir 1lıman iklim meyvesi olup, paleoboral orman aleminin bitkilerindendir. (Bulut, 2006: 174). Dünyanın değişik iklim bölgelerinde özellikle de 1lıman iklimlerin Atlantik tipi, karasal tip ve Akdeniz tipinin yayılış alanlarında, doğal olarak yetişmektedir (Doğanay, 2007: 302).

Ülkemizde ise Anadolu'nun Karadeniz, Marmara ve Ege Bölgeleri gibi nemli koşulları orman alanlarında Castanea Sativa Mill türü kestane doğal olarak yetişmektedir (Subaşı, 2004).

Çin Halk Cumhuriyeti’nin en önemli paya sahip olduğu Dünya kestane üretiminde; Türkiye yaklaşık 60 bin ton üretim ile ikinci sırada yer almaktadır. Bölgeler itibariyle üretimde Ege Bölgesi toplam üretimde yaklaşık \% 70'lik payla ilk sırayı almıştır. İller itibariyle üretimde ise sırasıyla Aydın, İzmir, Kastamonu ve Sinop ön plana çıkmaktadır. Dünya Kestane ithalatı 2012 yılında 50,1 milyon dolar büyüyerek 2011'a göre \% 19 civarında bir 
büyüme göstermiştir. Pazarın büyüklüğü 2012 yılında 308 milyon dolar mertebesindedir. Dış ticaret potansiyeli bakımından en yüksek ithalat hacmine sahip ilk iki ülkenin \% 20,4'lük pay ile Japonya ve \% 16,5 'luk pay ile İtalya'dır (ATB, 2013).

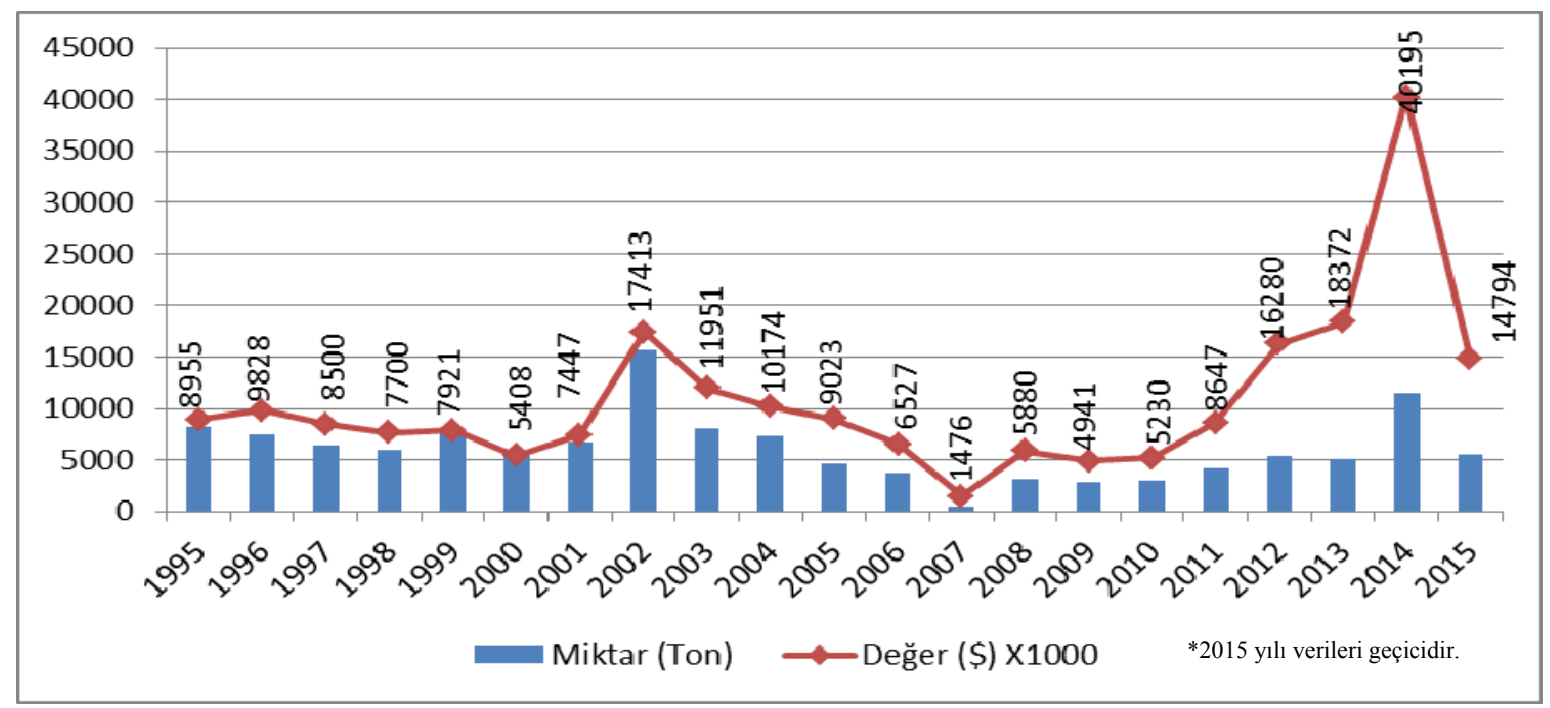

Şekil 3.1 Türkiye kestane ihracat miktar ve parasal değerleri (TÜİK, 2016; Kurt, 2011)

Türkiye'nin Kestane ihracat rakamlarına bakıldığında 1995 yılında 8287 ton olan ihracatın 2002 yılında \%89,5 artarak 15700,5 tona ulaştığı, ihracat gelirinin ise \%94,5 artışla 17.413 .000 dolara yükseldiği görülmektedir. 2007 yılında ise bu ihracat 2002 yılına oranla \%97 azalarak 520,1 tona gerilemiştir. Böylece aynı yılın ihracat geliri, 2002 yılına göre \%92 azalarak 1.476.000 dolara düşmüştür. 2007 yılı verilerine göre 2014 yılında kestane ihracatı \%2103 artarak 11462 tona çıkmış ve ihracat geliri de \%2623 artarak 40.195.000 dolar olmuştur.

2015 yılında Türkiye'den en çok kestane ithal eden ülkeler ise sırasıyla İtalya (2476 ton), Lübnan (1912 ton), Ürdün (388,6 ton) ve Almanya (186,7 ton) olmuştur (TÜİK, 2016).

\subsection{Defne ihracatı}

Defne 8-10 m. boylanabilen her dem yeşil bir ağaçtır. Akdeniz bitkilerinden olup, Akdeniz iklimine özgü maki denilen bitki örtüsünün karakteristik bir türüdür. Defne genel olarak Akdeniz iklim bölgesinde; Portekiz, İspanya, İtalya, Yugoslavya, Yunanistan, Türkiye ve Afrika'nın güney sahil bölgelerinde bulunur. Türkiye'de 600-800 m. Yüksekliklere değin, Hatay’dan başlayarak Kuzeydoğu Karadeniz’e kadar bütün kıyılarda, diğer türler içerisinde küme ve gruplar halinde yayılış gösterir (Acar, 1987).

Türkiye defnenin dünyadaki bir numaralı üretici ve tedarikçisidir. Türkiye'de 600-800 m. yüksekliklere değin, Hatay'dan başlayarak Kuzeydoğu Karadeniz'e kadar bütün kıyılarda yetişebilen bitki, daha çok diğer türler içerisinde küme ve gruplar halinde yayılış göstermektedir. Ülkemizde üretilen kuru defne yaprağının hemen hemen tamamı dış pazarlarda değerlendirilmekte, iç pazarda tüketimi ise sınırlı kalmaktadır. Yıllık ortalamalara bakıldığında kuru defne yaprağı ihracatımız yıllara göre değişmekle beraber 60-65 ülkeye yapılmakta olup yıllık ihracat miktarı da ortalama 4 bin ton dolaylarındadır. Dünya kuru defne yaprağı ihtiyacının \%95'ini ülkemiz karşılamakta, her yıl \% 5' lik artan bir oranda da talep gelmektedir. İthalat bazı yıllar yapılmakta olup ortalama yıllık 250-300 ton dolaylarındadır. İhracatı yapılan tıbbi ve aromatik bitkiler listesinde ilk sıralarda yer almaktadır (URL-4 2011; URL,5 2016) 


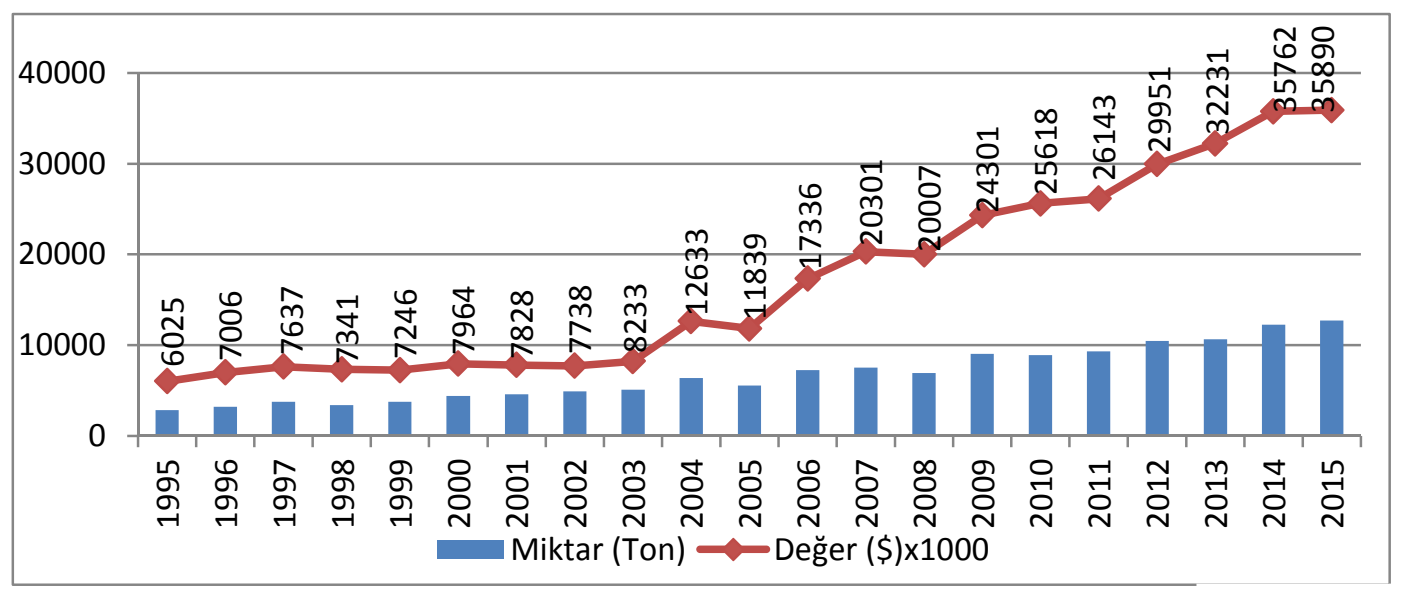

*2015 y1l verileri geçicidir

Şekil 3.2 Türkiye defne ihracat miktar ve parasal değerleri (TÜiK, 2016; Kurt, 2011)

Yıllar itibariyle ihracat miktarlarına ve değerlerine bakıldığında 1995 yılında 2870 ton ile gerçekleşen defne ihracatının, 6.025.000 dolar gelir sağladığı görülmektedir. Bu rakamlar 2006 yılında \% 153 artışla 7262 tona ulaşmış, aynı yıl ihracat geliri \%187 artarak 17.336.000 dolar olmuştur. 2014 yılında ise 2006 yılına göre ihracat miktarı \%69 ve ihracat geliri ise \%106 artarak 12255 tona ve 35.762 .000 dolara çıkmıştır. En çok ihracat yapılan ülkelere bakıldığında 1960 yılından bu yana İngiltere, İsviçre, Romanya, ABD, Rusya, Kanada, Almanya, Hollanda, Suriye, Avusturya'ya defne yaprağı ve defne yağı ihracatının yapıldığı görülmektedir. 1997- 2003 yılları arasındaki verilere göre sırasıyla Hong Kong, ABD, Almanya, Brezilya, Japonya, Polonya, Hollanda ve Fransa Türkiye'den defne yaprağı ithal eden ilk sekiz ülke olarak siralanmaktadır (URL-4 2011). 2015 yılı ihracat değerlerine bakıldığında ise en fazla defne yaprağı ihracatının Vietnam (7265 ton), Brezilya (529,4 ton), Polonya (523,5 ton), ABD (492,4 ton), Singapur'a (418,4 ton) yapıldığı ve bunu sirasiyla Japonya (250 ton), Almanya (211 ton), Filipinler (199,8 ton), Güney Afrika (195 ton) ve Mali'nin (190 ton) takip ettiği görülmektedir (TÜİK, 2016).

\subsection{Kekik ihracatı}

Kekik dünyada üretim ve tüketimi sınırlı olan bir bitkidir ve dış ticaret hacmi 10 bin ton civarındadır. Türkiye dünyada en fazla kekik ihraç eden ülke olup, dünya kekik talebinin 6-7 bin tonunu karşılamaktadır. Bu miktarın da \%95'i doğadan, \%5'i özel arazilerdeki üretimden elde edilmektedir. Dünya kekik ihracatında Türkiye’yi 1500-2000 ton ile Meksika izlemektedir. Ayrica Yunanistan (300-400 ton), İsrail (200-300 ton), Arnavutluk (200-300 ton) ve Fas (50-150 ton) kekik ihracatı yapan ülkeler arasındadırlar (Sarı ve Oğuz, 2000).

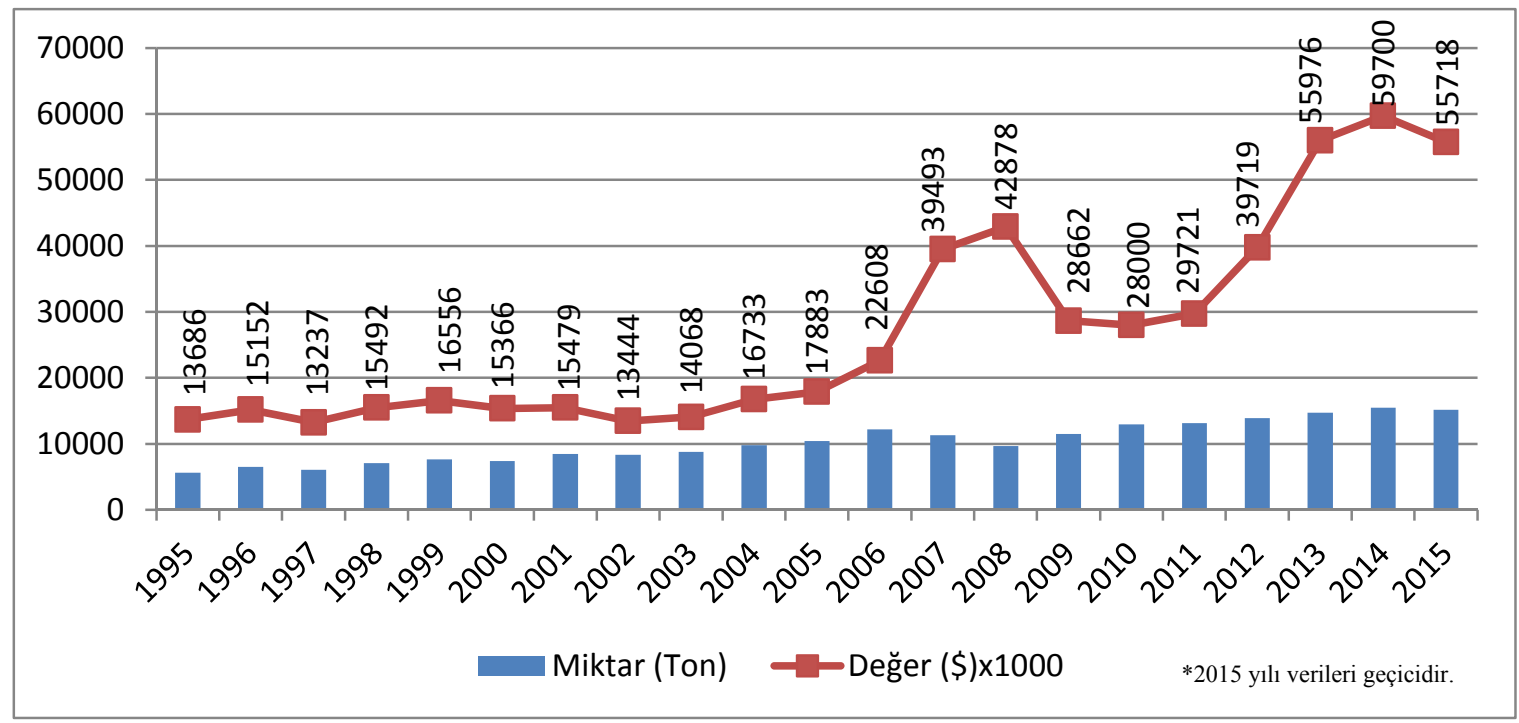

Şekil 3.3 Türkiye kekik ihracat miktar ve parasal değerleri (TÜİK, 2016; Kurt, 2011) 
1995 yılında 5601 ton olan kekik ihracatı, 13.686.000 dolar gelir sağlamıştır. 2008 yılında bu miktar \%72,9 artarak 9682,7 tona çıkmıştır. Bu artışla ihracat geliri de \%213 artarak 42.878.000 dolar olmuştur. 2010 y1lında ise 12912,7 ton kekik ihraç edilerek 2008 yılına göre \%33,3 artış sağlanmasına rağmen ihracat geliri \%34,7 gerileyerek 28.000.000 dolara düşmüştür. 2014 yılında 2010 yılı verilerine göre, ihracat miktarı \%20 artarak 15490,9 tona, ihracat geliri de \%113 artarak 59.700.000 dolara ulaşmıştır.

TÜİK verilerine göre 2015 yılında Türkiye'den kekik ithal eden ülkelerin başlıcaları sırasıyla; ABD (3640 ton), Almanya (1796 ton), Hindistan (412 ton), Polonya (449 ton) olmuştur. Bunu Avustralya (311 ton) suriye (260 ton), Hollanda (251 ton) ve kanada (239 ton) takip etmiştir (TÜİK, 2016).

\section{4 Çam Fıstığı ihracatı}

Fıstık çamı Pinus pinea L. Akdeniz fitocoğrafya bölgesinin doğal bir elemanıdır (Atalay, 1994). Dünya'da Türkiye başta olmak üzere Akdeniz ikliminin etkili olduğu Portekiz ve İspanya'da 1000m yüksekliğe kadar, Doğu İtalya Dalmaçya Makedonya ve Girit Adası'nda lokal yayılış gösterir (Orçun 1972; Eltez vd., 2013).

Çam fıstığı, fıstık çamı ağacı kozalaklarından elde edilir. Üretici gelirleri içinde oldukça önemli bir paya sahip olup, gıda sanayiinde kullanılır (Anşin ve Özkan, 1997). Çam fistığının dünya pazarlarına yıllık global sürüm miktarı 20000 ton civarındadır. Bu pazarda 10000 tonluk üretim ile Çin Halk Cumhuriyeti ilk sırada yer alır. Bunu Pakistan-Afganistan 5000 ton, İspanya 3000 ton, Türkiye 1200 ton, Portekiz 850 ton ve İtalya 400 ton ile takip etmektedir (Bilgin ve Ay, 1997).

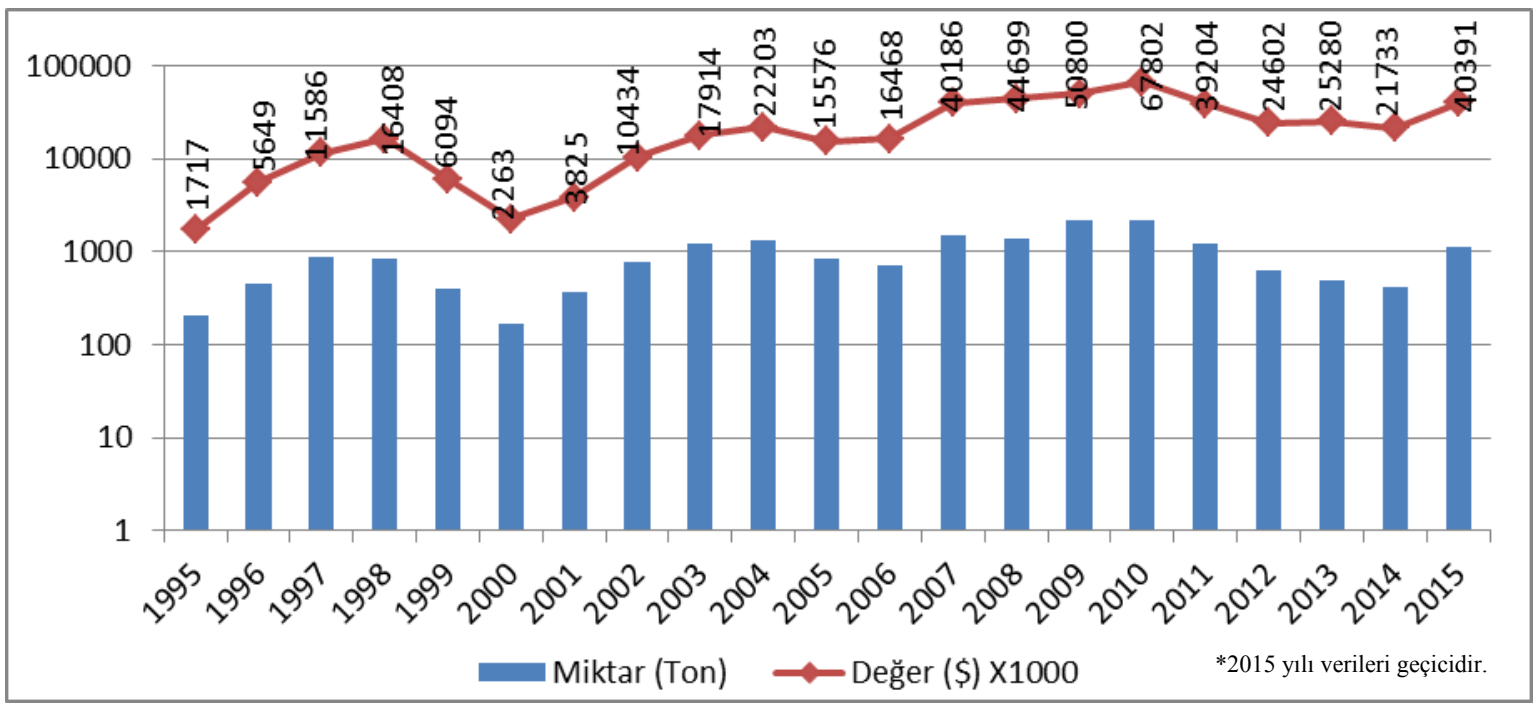

Şekil 3.4 Türkiye çam fıstığı ihracat miktar ve parasal değerleri (TÜİK, 2016; Kurt, 2011)

Türkiye'nin çam fıstığı ihracat rakamları incelendiğinde 1995 yılında 203 ton ile 1.717.000 dolar gelir sağlayan ihracatın, 2000 yılında \%18,3 azalarak 166 tona düştüğü, ancak ihraç geliri miktarının ise tersine \%31,8 artarak 2.263.000 dolara yükseldiği görülmektedir. 2010 yılında ise 2000 yılı verilerine göre ihracat miktarı \%1208 artarak 2171,766 tona ulaşmıştır. Bu artışla birlikte ihracat geliri de \%2896 artarak 67.802.000 dolara çıkmıştır. 2015 yılında ise ihracat miktarı 2010 yılına göre düşüş göstermiş ve \%49,2 azalarak 1.104,243 tona gerilemiştir. Buna paralel olarak aynı yıl ihracat geliri de \%40,5 gerileyerek 40.391.000 dolar olmuştur.

Günümüzde Türkiye'den çam fistığı ihracatı dünyanın her tarafına yapılmakla beraber, 1997-2003 yılları arasında EİB'den (Ege İhracatçılar Birliği) en çok çam fıstığı satın alan ilk 5 ülke sırasıyla İtalya (246 ton), İspanya (52 ton), ABD (45 ton), İsviçre (43 ton), Almanya (19 ton)'dır (EİB, 2003). 2015 yılı itibariyle ise Türkiye'den en fazla çam fistığı ithal eden ülkeler İtalya (584,9 ton), Almanya (284,6 ton) ve İspanya (75,2 ton) şeklinde sıralanmıştır (TÜİK, 2016).

\subsection{Kimyon ihracatı}

Kimyon Tıbbi ve Aromatik bitkilerden olup genellikle baharat ve ilaç sektöründe kullanılan kazık kök yapısına sahip bir bitkidir (URL-6, 2016). Maydanozgiller (Apiaceae) familyası içerisinde yer alan kimyonun genel 
olarak en sık yetiştiği yerler: İran, Özbekistan, Tacikistan, Türkiye, Fas, Mısır, Hindistan, Suriye, Meksika ve Şili'dir. Türkiye'de, Ege ve Karadeniz Bölgesinde kültür olarak yetiştirilir (URL-7, 2016).

Kimyon ihracat miktar ve değerinde üretim miktarına ve dünya piyasalarına bağlı olarak önemli dalgalanmalar olmakta ve Türkiye de bu dalgalanmalardan büyük ölçüde payını almış bulunmaktadır. Türkiye dünya kimyon piyasasında en önemli ihracatçı ülke konumundadır. Dünyada en fazla kimyon üretiminin yapıldığı ülke Hindistan'dır. Ancak Hindistan da baharat kullanımının ve özellikle kimyon tüketiminin fazla olması nedeniyle, üretilen kimyon ancak ülkenin iç tüketimine cevap vermektedir. Dünyada 50 bin ton olan kimyon tüketiminin büyük çoğunluğunu Türkiye, Hindistan ve Suriye karşılamaktadır. Kimyonu başta Latin Amerika ülkeleri olmak üzere, ABD, Avrupa, Singapur ve diğer Uzakdoğu ülkelerine ihraç etmektedir. 2004 tarım politikaları ulusal merkezi beyanlarına göre Türkiye'de üretilen kimyonun dünya çapında kalitesi ve yararları yönünden birinci derecede yer alırken tarım ürünleri ihracatında $\% 1,2$ oranından $\% 4,4$ oranına yükseldiği görülmektedir (URL-8, 2011).

İklim koşulları ve Türkiye'de üretilen kimyonun dünya fiyatlarının çok üzerinde olması nedeniyle üreticinin vazgeçmesi sonucu üretimi hızla düşen kimyonun ihracatı da giderek azalmaktadır (URL-9, 2011).

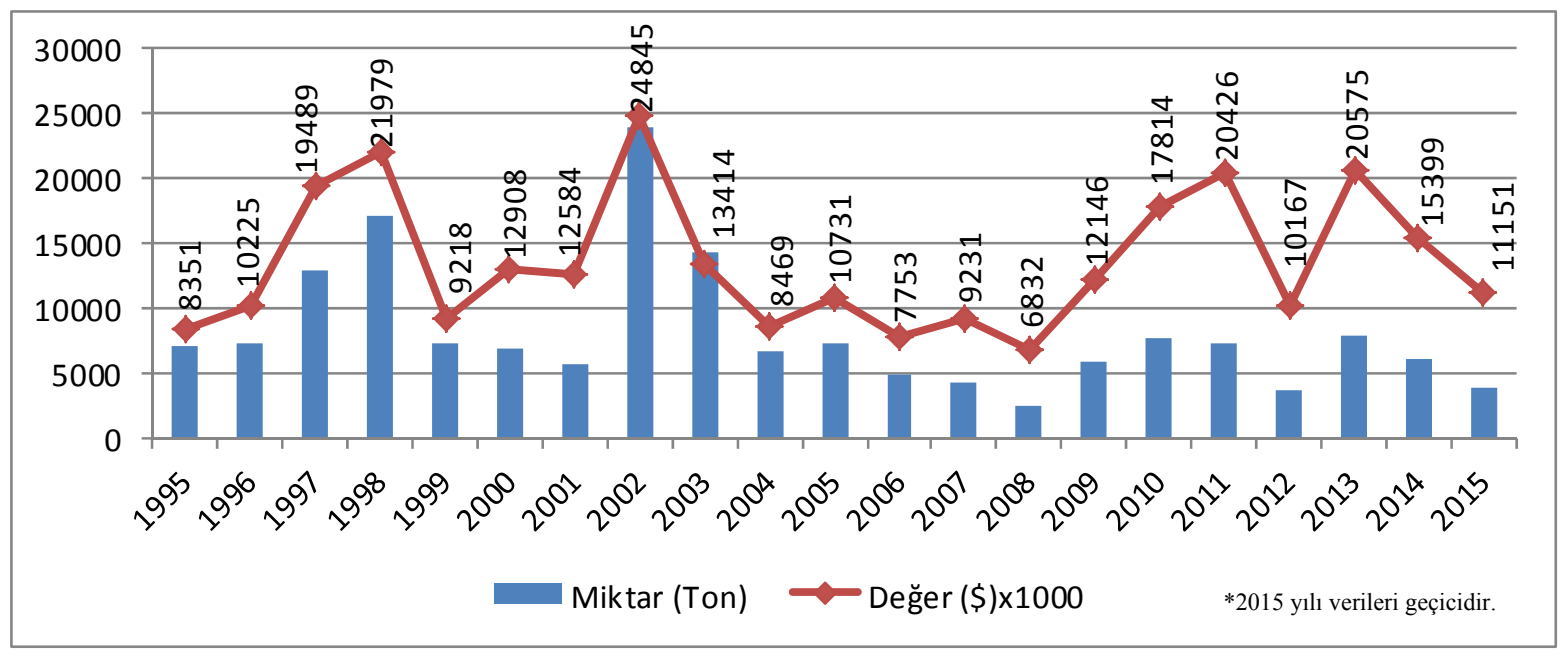

Şekil 3.5 Türkiye kimyon ihracat miktar ve parasal değerleri (TÜiK, 2016; Kurt, 2011)

Türkiye'nin kimyon ihracat miktar ve değerlerine bakıldığında 1995 y1lında 7002 ton olan ihracatın, 2002 yılında \%240 artarak 23834,4 tona ulaştığı görülmektedir. Aynı yıllarda ihracat geliri ise 8.351 .000 dolardan \%197 artışla 24.844 .000 dolara ulaşmıştır. Ancak bu değer 2008 yılında \%90 düşüşle en düşük ihracat miktarı seviyesine yani, 2366 tona gerilemiş̧ir. Bunun birlikte ihracat geliri ise 6.832 .000 dolara kadar düşüş göstermiştir. 2013 yılında ise kimyon 2008 yılında göre \%235 artarak 7941 ton ihraç edilip 20.575.000 dolar gelir sağlamıştır.

Türkiye'nin 2015 yılında en fazla kimyon ihraç ettiği ülkeler ise sırasıyla Bangladeş (1123,2 ton), ABD (763,8 ton), Almanya (408,3 ton), Singapur (179,3 ton), Fransa (171,2 ton), Japonya (151 ton) ve Hollanda (141,3 ton) olmuştur (TÜiK, 2016).

\subsection{Anason ihracatı}

Anason (Pimpinella anisum L.) yaklaşık 1500 yıldır, eski Mısırlılar'dan beri kültürü yapılan bir bitkidir. Ülkemizde tıbbi ve baharat bitkileri arasında önemli bir yere ve ihracat payına sahiptir. Anason \%1-6 oranında uçucu yağ içerir ve yağın \%70-85'ni anetol oluşturur. Anason uçucu yağı alkollü içeceklerde aroma verici olarak kullanılır. Ayrıca anason baharat olarak kullanıldığı gibi mideyi kuvvetlendirici ve öksürüğe karşı olan olumlu etkisinden dolayı eczacılıkta da kullanılır. Ülkemizde anason çiçeklenme döneminde yağış almayan geçit bölgelerine adapte olmuştur. Anason ekilişinin \% 87'si İç Ege, \%12'si ise Akdeniz Bölgesi'ndedir ve yıllık üretimi 8-15 bin ton civarındadır. Anason çoğunluğu Denizli, Burdur, Muğla, Antalya illerinde olmak üzere daha az oranda da Bursa, Balıkesir, Afyon, Uşak ve İzmir illerinde yetiştirilmektedir. Üretimin bir bölümü başta ABD olmak üzere değiş̧ik ülkelere ihraç edilmektedir. Yıılık ihraç miktarı 3-4 bin ton ve elde edilen gelir de 5-10 milyon Amerikan Doları arasında değişmektedir. Ülkemiz dışında diğer Akdeniz ülkeleri, Hindistan, Güney Rusya, Meksika, Çin, Afganistan ve Güney Amerika'da da tarımı yapılmaktadır (URL-10, 2016). 
2015 TÜİK kayıtlarına bakıldığında ise Türkiye'nin en fazla ihraç ettiği ülkeler ABD (705 ton), Almanya (507,5 ton), Hollanda (447 ton), Brezilya (370 ton ve Peru (333 ton) şeklinde sıralanmıştır (TÜİK, 2016).

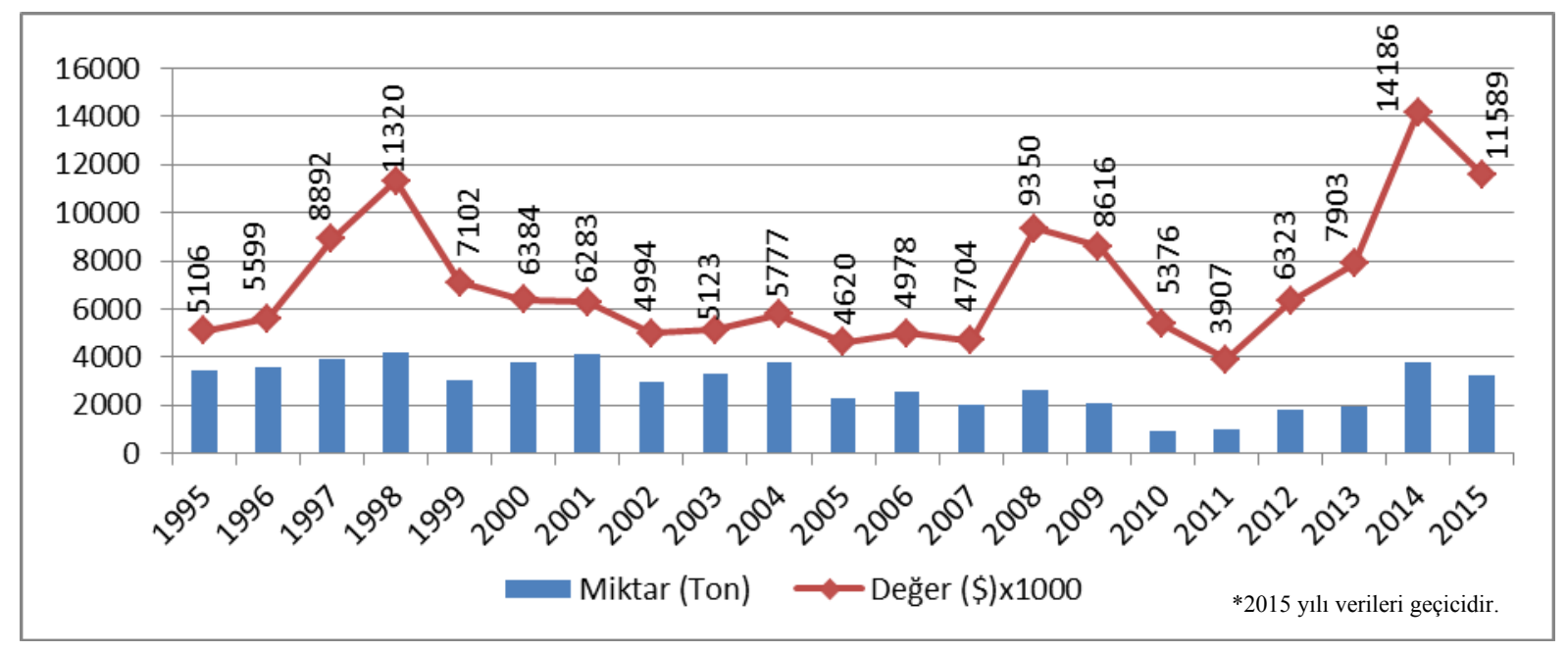

Şekil 3.6 Türkiye anason ihracat miktar ve parasal değerleri (TÜİK, 2016; Kurt, 2011)

1995 yılında 3417 ton ihraç edilen anason sonraki yıllarda dalgalı bir görünüm arz etmiş olup 2008 y1lında \%23 azalmış ve 2658 ton ihraç edilmiştir. Ancak aynı yıl elde edilen gelir ise tam tersi \%83 artarak 5.106.000 dolardan 9.350.000 dolara çıkmıştır. 2014 yılında ise bu rakamalar 2008 yılına göre \%43 artışla 3808 tona yükselmiş ve 14.186.000 dolar ihracat geliri elde edilmiştir.

\subsection{Adaçayı ihracatı}

Ülkemiz florası Lamiaceae (Ballıbabagiller) familyasından çok yıllık bir bitki olan adaçayı türleri açısından dünyanın en zengin florasına sahip olup, ekonomik öneme sahip ve florada bol miktarda olan türlerin toplanıp ihraç edilmesi söz konusudur. Yurt dışı talebi sürekli olarak artış trendi içersinde olan adaçayı dünya adaçayı üretiminin \%30'unu karşılamaktadır (URL-11, 2011).

Son yıllar ortalamasına göre, ülkemizde en fazla dıș satımı yapılan tıbbi ve aromatik bitkiler içerisinde adaçayı \%3'lük bir pay ile 9. sırada yer almaktadır. İzmir'de birçok firma tarafından adaçayı ticareti yapılmaktadır. Hem yurt içinde tüketilen, hem de yurt dışına ihraç edilen adaçayı büyük oranda doğadan toplanmaktadır (Bayram ve Sönmez, 2006).

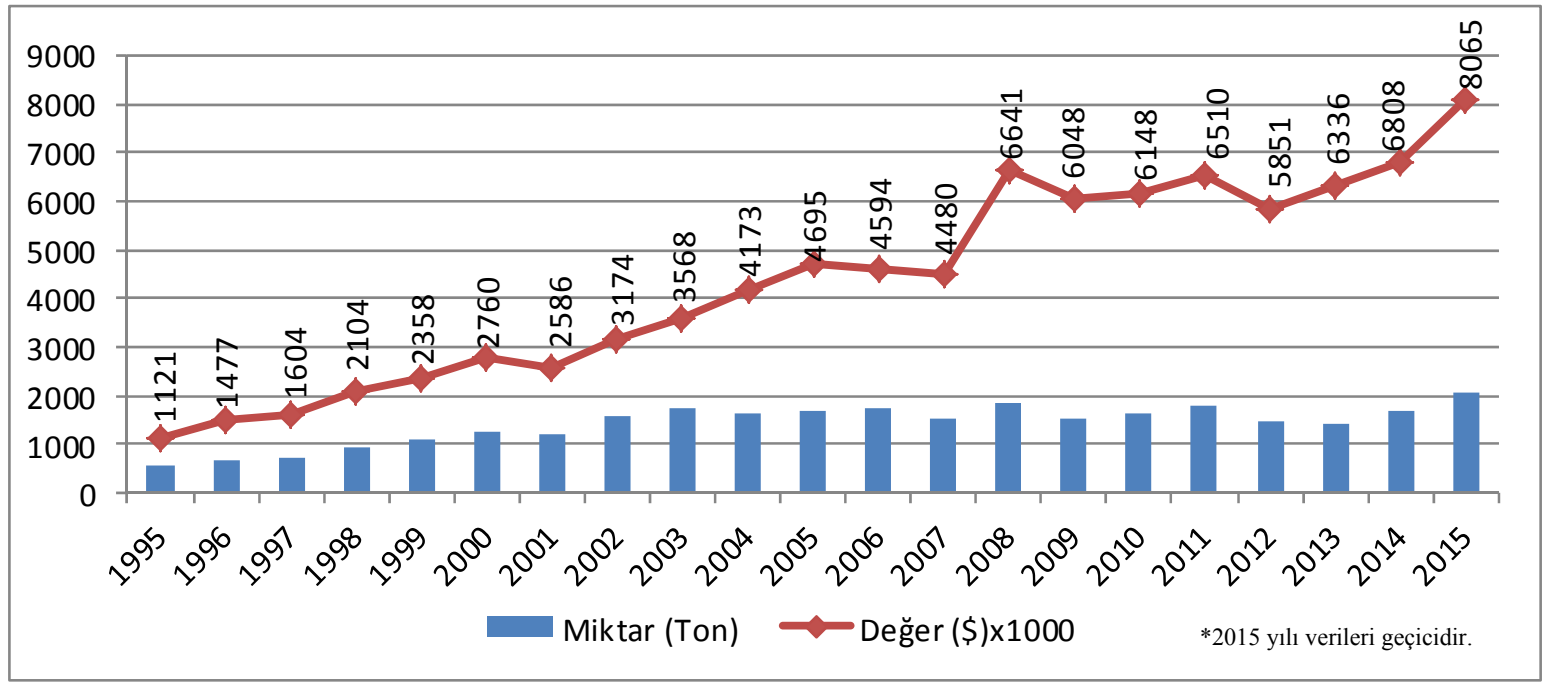

Şekil 3.7 Türkiye adaçayı ihracat miktar ve parasal değerleri (TÜİK, 2016; Kurt, 2011) 
Türkiye'nin Adaçayı ihracat rakamlarına bakıldığında ihracatın kademeli olarak artış gösterdiği görülmektedir.1995 yılında 547 ton ve 1.121 .000 dolar olan ihracat rakamları 2008 yılında \%240 artarak 1862 tonla 6.600 .000 dolara, 2015 yılında ise $\% 11$ artışla 2070 ton ve 8.065 .000 dolara ulaşmıştır.

EİB'nin 2010 yılı kayıtlarına göre Türkiye'den en fazla adaçayı ithal eden ülkelerin başında sırayla ABD (161 ton), İtalya (157 ton), Japonya (95 ton), İniltere (67 ton), Almanya (38 ton), Avustralya (30 ton) ve Kanada (22 ton) gelmektedir. Değer olarak bakıldığında ise en fazla gelir getiren ülkelerin sırayla İtalya (491 bin \$), Japonya (455 bin \$), ABD (248 bin \$), İngiltere (236 bin \$), Almanya (154 bin \$), Avustralya (97 bin \$) ve Kanada (53 bin \$) olduğu görülmektedir (EIB, 2010). 2015 yılı TÜiK kayıtlarında ise en fazla ihracat yapılan ülkeler ABD ( 115,9 ton), İspanya ( 98,8 ton), Japonya ( 96,8 ton), Polonya ( 86,4 ton) Almanya ( 72,8 ton) ve İtalya ( 51,7 ton) olmuştur (TÜiK, 2016).

\subsection{Ihlamur ihracatı}

Ihlamur; Ihlamurgiller (tiliaceae) familyasından Tilia cinsini oluşturan 30 kadar ağaç türünün ortak adıdır. Her yıl yaprakları dökülen bu ağaçlar, Kuzey Amerika'dan Meksika'ya, Avrupa'dan Asya'ya ve Japonya' ya kadar ılıman bölgelerde (65. enleme kadar) her yerde (ormanlarda) doğal olarak yetişir. Ayrıca Avrupa ve Kuzey Amerika'da kültürü yapılmakta olup, boyları 100 fit'e kadar ulaşabilir (Uslu, 2004).

Türkiye'de üç türü bulunan ıhlamur doğu Karadeniz, Marmara, Ege, Sahil şeridinde ve Antalya çevresinde yetişmektedir. Diğerlerine nazaran düşük olmasına rağmen önemli bir ihraç ürünümüzdür. Başta Bulgaristan olmak üzere balkan ülkeleri en büyük rakiplerimiz arasındadır (Kaplan, 2010).

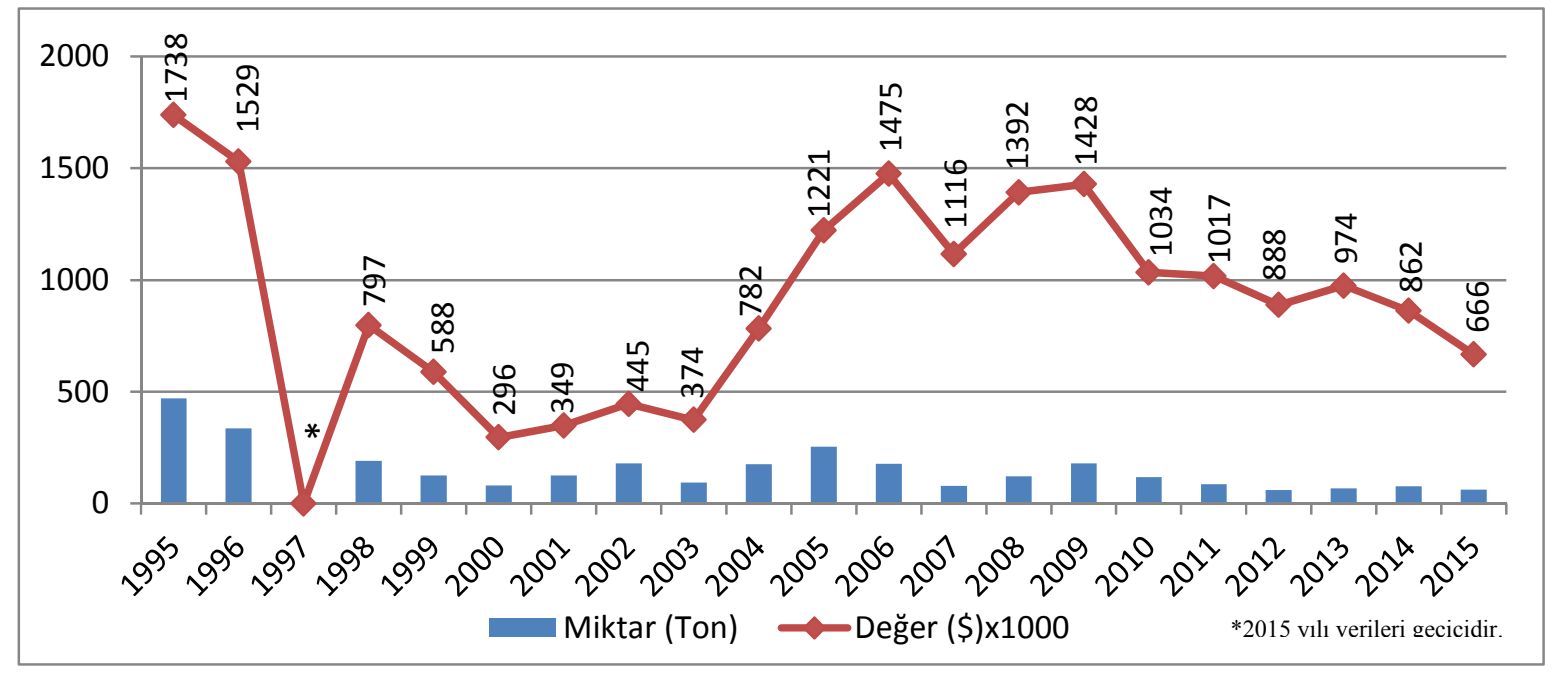

Şekil 3.8 Türkiye uhlamur ihracat miktar ve parasal değerleri (TÜiK, 2016; Kurt, 2011)

Ihlamur ihracat rakamlarına bakıldığında genel olarak 1995 yılından 2015 y1lına kadar kademeli bir düşüş gözlenmektedir. 1995 yılında 469 ton ve 1.738 .000 dolar ihracat rakamları ile en yüksek seviyede bulunan ihlamur, 2014 yılında $\% 84$ düşüşle 78 tona gerilemiş ve ihracat geliri \%50,5 azalarak 862.000 dolara düşmüştür.

2015 yılı TÜİK verilerine göre Türkiye'den en fazla 1hlamur ithal eden ülkeler sırasiyla Almanya (36,4 ton), Misır $(7,05)$ ve Dominik Cumhuriyeti (6,58 ton) olmuştur (TÜíK, 2016).

\section{SONUÇ VE ÖNERILER}

Türkiye zengin bitki çeşitliliğine, geniş bir yüzölçümüne ve farklı iklimlere sahip yapısıyla odun dışı orman ürünleri bakımından oldukça zengindir. Bu çeşitlilik Türkiye'nin odun dışı orman ürünleri üretim kapasitesini de önemli ölçüde etkilemekte ve bazı ODOÜ’lerin ihracatında ön sıralarda yer almasını sağlamaktadır. Özellikle defne, çam fistığı, kekik, kestane, kimyon, anason, adaçayı ve ıhlamur ihracatta öne çıkan ürünlerden bazılarıdır. 
Çalışmada adı geçen odun dışı orman ürünlerinin 1995-2015 yılları arasındaki 21 yıllık ihracat durumu incelenmiş ve elde edilen bu veriler tasnif edildikten sonra grafik halinde sunularak ylllar itibariyle meydana gelen değişmeler yüzdesel hesaplamalarla ortaya konulmuştur.

Genel olarak bakıldı̆̆ında 1995 yılından 2014 yılına kadar olan süreçte ihracat miktarının kekikte $(\% 376,5)$, defnede $(\% 327)$, adaçayında $(\% 208,9)$, çam fistığında $(\% 109,4)$ ve kestanede $(\% 38,3)$ artış gösterdiğí, kimyon $(\% 14.1)$, anason $(\% 11,4)$ ve ihlamurda $(\% 83,37)$ ise düştüğü görülmüştür.

Aynı süreçte ihracattan elde edilen parasal gelirler ise ıhlamur hariç artış göstermiştir. Artış miktarlarına bakıldığında çam fistığının yaklaşık \%1165, adaçayının \%507, defnenin\% 494, kestanenin \%349, kekiğin \%336, anasonun $\% 178$ ve kimyonun $\% 85$ daha fazla gelir sağladığı görülmüştür. Ihlamur ihracat geliri ise yaklaşık olarak \%50 oranında düşüş göstermiş̧ir.

Odun dışı orman ürünleri dünya genelinde olduğu gibi ülkemizde de gerek ekonomiye olan katkısı gerekse bölge halkının kalkınması açısından önemli yer tutmaktadır. Bu bakımdan ODOÜ’ye verilen önem her geçen gün artmakta ve elde edilen gelirlerde giderek katlanmaktadır. Ancak Türkiye ODOÜ kaynaklarına bakıldığında elde edilen gelirin ülke kapasitesinin çok daha altında olduğu da yadsınamaz bir gerçektir. Bu bağlamda biyoçeşitlilik bakımından zengin olan ülkemizde odun dışı orman ürünlerinin üretim kapasitelerini ve bu ürünlerden daha fazla faydalanma yollarının araştırılması gerekmektedir.

Türkiye Odun dışı orman ürünleri ihracatını artırmak için özellikle ülkemizde önde gelen ürünlerin envanter ve yayılış alanları belirlenerek koruma altına alınması ve en uygun toplanma zamanlarının belirlenerek maksimum verim elde edilmesi sağlanmalıdır. Özellikle tıpta ve eczacılıkta kullanılan bazı odun dışı orman ürünlerinin kültürü yapılarak alternatif üretim olanaklarının geliştirilmesi ve ihracatta önemli olan bazı odun dışı orman ürünlerinin teşvik edilerek arz açığının kapatılması ve ihracat gelirinin arttırılması sağlanmalıdır.

\section{KAYNAKLAR}

o Acar, İ. 1987. Defne Yaprağı ve Yaprak Eterik Yağının Üretilmesi ve Değerlendirilmesi. Ormancılık Araştırma Enstitüsü Yayınları, Teknik Bülten Serisi No:186, Ankara, 89 s.

o Anşin, R. ve Özkan, Z. 1997. Tohumlu Bitkiler, Karadeniz Teknik Üniversitesi Orman Fakültesi, Yayın No:197, Trabzon, $507 \mathrm{~s}$.

o Atalay, İ. 1994. Türkiye Vejetasyon Coğrafyası. Ege Üniversitesi Basımevi, İzmir, 336 s. ,

o ATB 2013. 2013 Yılı Kestane Raporu. Aydın Ticaret Borsası, http://aydinticaretborsasi.org.tr/files/document/pdf/kestane-raporu.pdf, (22.11.2015).

o Balcı, Ö. 2011. Odun Dışı Bitkisel Ürünler. Bitkisel Ürünler Şube Müdürlüğü, Uluslararası Orman Yı1l, www.ogm.gov.tr (12.11.2015).

o Bayram, E. ve Sönmez, Ç. 2006. Adaçayı Yetiştiriciliği, E.Ü. Ziraat Fakültesi, Tarla Bitkileri Bölümü, Yayım Bülteni No: 48.

o Bilgin, F. ve Ay, Z. 1997. Ege Bölgesinde Çam fistığı İşletmeciliği Üzerine Araştırmalar. Orman Bakanlığı Ege Ormancılık Araştırma Müdürlüğü, Orman Bakanlığı Yayın No:045, İzmir, 49 s.

o Bulut, İ. 2006. Genel Tarım Bilgileri ve Tarımın Coğrafi Esasları (Ziraat Coğrafyası). Gündüz Eğitim ve Yayıncilik, Ankara.

o Doğanay, H. 2007. Ekonomik Coğrafya 3: Ziraat Coğrafyası, Aktif Yayınevi, İstanbul.

o DPT 2001. VIII. Beş Yıllık Kalkınma Planı. Ormancılık Özel İhtisas Komisyon Raporu, Devlet Planlama Teşkilatı Yayınları, ISBN 975-19-2555-X, Ankara, 539 s.

o EİB 2003. Ege İhracatçıları Birlikleri Kayıtları. İzmir, http://www.egeliihracatcilar.com.

o EİB 2010. Ege İhracatçıları Birlikleri Kayıtları. İzmir, http://www.egeliihracatcilar.com.

o Eltez, R. Z., Kaplanoğlu, E., Meriç M. K. ve Eltez, S. 2013. Bergama kozak yaylası çam fistığı işleme tesislerinin durumu, sorunları ve çözüm önerileri. Ege Üniversitesi Ziraat Fakültesi Dergisi, 2015, 51(1):3140.

o Kaplan, E. 2010. Ormanlarımızda Odun Dışı Orman Ürünleri. Orman Genel Müdürlüğü, Antalya, 35 s.

o Killmann, W., Ndeckere, F., Vantomme, P. ve Walter, S. 2003. Developing inventory methodologies for the elaboration of national level statistics on NWFP: Lessons learned from case studies and from a global assessment. Sustainable Production of Wood and Non-Wood Forest Products, March 11-12, New Zealand, 604 (5): 83-87. 
o Kurt, R. 2011.Türkiye Odun Dışı Orman Ürünlerinin Mevcut Durumu ve Dış Ticaret Analizi. Yüksek Lisans Tezi, Bartın Üniversitesi, Bartın, 141 s.

o Orçun, E. 1972. Özel Bahçe Mimarisi Dendroloji Cilt I: İğne Yapraklı Ağaç ve Ağaçcıklar, Ege Üniversitesi Ziraat Fakültesi Yayın No: 196, 383 s.

o Sakarya, S. ve Canlı, Ş. 2011. Orta Anadolu Ağaç Mamulleri ve Orman Ürünleri İhracatçıları Birliği (OAİB). Odun Dışı Orman Ürünleri ( Orman Tali Ürünleri) Sektör Raporu, $16 \mathrm{s.}$

o Sarı, A. O. ve Oğuz, B. 2000. Türkiye ve Dünyada Bazı Tıbbi, Kokulu ve Baharat Bitkilerinin Yeri ve Önemi. TYUAP: Ege-Marmara Dilimi 2000 yılı tarla bitkileri bilgi alıs-veriş toplantısı bildirileri, Ege Tarımsal Araştırma Enstitüsü ,Yayın No:98, İzmir, s.241-248.

o Subaşı, B. 2004 Kestane Sektör Profili. İstanbul Ticaret Odası, Etüt ve Araştırma Şubesi, 19 s.

o TÜİK 2016. Türkiye istatistik Kurumu Kayıtları. Ankara.

o URL-1 2016. Yeşilırmak Havzasında Kırsal Nüfusun Odun Dış1 Orman Ürünleri Farkındalı̆ğ (KORUP). http://www.yesilirmak.org.tr/userfiles/file/ODOU_KORUP.pdf (10.01.2016).

o URL-2 2015. Odun dışı orman ürünleri ihracat1 2010 yılında 221 milyon dolar olarak gerçekleşti. http://www.marbleport.com/marble_port/guncelhaberler/2846/ (11.12.2015)

o URL-3 2016. Odun Dış1 Orman Ürünlerinde İhracat Hedefi 500 Milyon Dolar. http://www.ormansu.gov.tr/osb/HaberDuyuru/guncelHaber/14-0717/Odun_D $\% \mathrm{C} 4 \% \mathrm{~B} 1 \% \mathrm{C} 5 \% 9 \mathrm{~F} \% \mathrm{C} 4 \% \mathrm{~B} 1 \_$Orman_\%C3\%9Cr\%C $3 \%$ BCnlerinde $\% \mathrm{C} 4 \% \mathrm{~B} 0 \mathrm{hracat}$ Hedefi 500_Milyon_Dolar.aspx?sflang=tr $(15.01 .2016)$.

o URL-4 2011. Defne Yaprağ1 İlaç Oldu. http://www2.ogm.gov.tr/basin1/detay.aspx?duyuruno=585 (28.03.2011).

o URL-5 2016. Defne Yaprağı ve Defne Yetiştiriciliği. http://www.arsivbelge.com/yaz.php?sc=3291 $(05.02 .2016)$

o URL-6 2016. Kimyon Tarımı (Yetiştiriciliği). http://www.eziraatci.com/kimyon-tarimi-yetistiriciligi/html $(06.02 .2016)$

o URL-7 2016. Kimyon, Dağılımı. https://tr.wikipedia.org/wiki/Kimyon (06.02.2016).

o URL-8 2011. Kimyon Üretimimiz Uluslararas1 Fiyatları Belirliyor. http://www.sana.sy/tur/239/2010/11/04/317177.html (21.01.2011).

o URL-9 2011. Bu Yil Kimyonda İhracat Yok. http://www.haberler.com/bu-yil-kimyonda-ihracat-yok4013974-haberi/ (21.01.2011).

o URL-10 2016. Endüstri Bitkileri Yetiştiriciliği. http://bursa.tarim.gov.tr/kestel/Sayfalar/Detay.aspx?SayfaId=4 (07.01.2016).

o URL-11 2011. Gida Sanayii, Ekonomi, http://www.gidasanayii.com/modules.php?name=News\&file=print\&sid=4522 (18.01.2011).

o Uslu, J., 2004. Ihlamur sektörü profili. İstanbul Ticaret Odası, Bilgi Ve Doküman Yönetimi Şubesi, 22 s. 